\title{
Codificação das Leis Sociais no Brasil *
}

\author{
A. F. Cesarino Júnior \\ Presidente Honorário da Sociedade Interna- \\ cional de Direito do Trabalho e da Segurança \\ Social (Genebra) - Professor Honorário da \\ Universidade Central da Venezuela (Caracas) \\ - Professor Catedrático da Universidade Es- \\ tađual (São Paulo).
}

\begin{abstract}
SUMÁrio - 1 - Codificação das Leis Sociais no Brasil. 2 - Os primeiros projetos de Código do Trabalho. Razão de sua não aprovação. 3 - $O$ desenvolvimento $d a$ legislação social brasileira. 4 - A Consolidação das Leis do Trabalho. Sua elaboração. Crítica. Razão de ser de sua permanência. 5 - Legislação posterior à CLT. 6 - Comissões nomeadas pelo Ministro do Trabalho. Código do Trabalho. Código de Processo Civil do Trabalho. 7 - Os novos projetos do Código do Trabalho. 8 Projeto SbGadas viana. 9 - Projeto CARLOS LACERDA. 10 - Projeto da Comissão Mista de Revisão da ClT. - A Codificação das Leis de Seguro Social. 12 - O Instituto de Serviços Sociais do Brasil. 13 - O projeto da Comissão do Bem Estar Social. 14 - A Lei Orgânica de Previdência Social. 15 - Conclusões.
\end{abstract}

1. A codificação das leis sociais no Brasil ainda é um problema. Com efeito, a vigente Consolidação das Leis do Trabalho não é ainda o Código do Trabalho, por motivos que adiante exporemos. Ademais, no seu art. 12 declara

* Tese apresentada ao I Congresso Nacional de Direito do Trabalho e da Segurança Social realizado de 25 a 30 de abril de 1960, em Tucuman, República Argentina. 
ela expressamente que os preceitos concernentes ao regimen de seguro social são objeto de lei especial. E a Lei Orgânica da Previdência Social ainda não existe entre nós, apesar de bem adiantada a sua tramitação parlamentar, como se mostrará oportunamente.

2. A primeira tentativa de se estabelecer um Código do Trabalho no Brasil foi feita em 1917, pelo deputảdo Maurício DE LACERda, que apenas sugeriu a apresentação do respectivo projeto. Este foi elaborado pela Comissão de Constituição e Justiça da Câmara dos Deputados, reunindo vários projetos de lei em andamento, inclusive um datado de 1904. O Código de Trabalho compreendia nada menos de 107 artigos em 6 títulos, distribuida a matéria do seguinte modo: disposições preliminares; do contrato de trabalho; do dia de trabalho; dos acidentes do trabalho; disposições gerais e disposições finais.

Conforme lembra Jarbas Peixoto, não teve êxito porque, náo sòmente inexistia uma legislação social anterior, que se pudesse ao menos consolidar, como também diante da resistência encontrada. Deveu-se ela ao caráter rigorosamente privatista da formação jurídica das elites culturais e governativas do país. O Código do Trabalño foi qualificado de "aberração legislativa", que cerceava a liberdade de contratar serviços e violava o art. $72, \S 24$, da Constituição Federal, que garantia a liberdade de profissão. Assim venceu o ponto de vista contrário à intervenção do poder público no sistema das relações de trabalho entre operários e patrões, salvaguardando a intangibilidade contratual de uns e de outros.

O projeto foi reduzido a simples Lei Operária e finalmente a Lei de Acidentes do Trabalho, a primeira que tivemos, de n. 3.724 , de 15 de janeiro de $1919^{1}$.

1. Cf. JaRbas PeIXото, Código do Trabalho, Rio, 1945, pgs. 66 a 71 , ns. 43 a 46 . 
3. Posteriormente a essa tentativa, com a vitória da Revolução de 1930 , as leis sociais se desenvolvem extraordinàriamente no Brasil. Basta lembrar que, de acôrdo com um trabalho elaborado por alunos em nosso Seminário de Legislação Social, da Faculdade de Direito, da Universidade de São Paulo, ${ }^{2}$, havia no Brasil 492 diplomas legais relativos ao Direito Social ${ }^{3}$.

Êsse grande número de leis tornava difícil a sua aplicação, já de si complicada pelo fato de se tratar de um direito novo, que, como vimos, repugnava à mentalidade civilista da quase totalidade dos nossos juristas daquela época.

4. Tão grande número de leis impôs a necessidade de sua consolidação, o que foi realizado pelo decreto-lei $n$. 5.452 , de $1 .^{\circ}$ de maio de 1943 . É êle não apenas uma compilação ordenada da legislação em vigor nessa data, mas contém várias alterações à margem. Não compreende, porém, tôda a legislação social vigente, por isso que não inclui a de previdência social, nem a de acidentes do trabalho, para citar sòmente os assuntos mais importantes não consolidados.

Divide-se a Consolidaçãa das Leis do Trabalho em onze títulos, relativos a Introdução, Normas Gerais de Tutela do Trabalho, Normas Especiais de Tutela do Trabalho, Contrato Individual de Trabalho, Organização Sindical, Contrato Coletivo de Trabalho, Processo de Multas Administra-

2. Pérsio Furquim Rebouças e Júlio Horst Zadrozny, Elenco Geral da Legislação Social Brasileira, de 1903 a 1940, in revista "Legislação do Trabalho", São Paulo, 1940, vol. IV, pgs. 465 a 499.

3. O número exato é um pouco menor, pois a redação da revista pediu aos AA., a inclusão no elenco de disposições concernentes a funcionários públicos, estranhas, portanto, à legislação social. Mais tarde publicaram êles um suplemento com mais 122 diplomas legais (cit. revista, vol. V, pgs. 64 a 71). SoUZA NENo organizou uma compilação das mesmas leis, que compreendia, em 1941, 3 vols., com 2.137 pgs. (Cf. Legislação Trabalhista, São Paulo, 1939; suplemento, 1940; 2. ${ }^{\circ}$ suplemento, 1941). 
tivas, Justiça do Trabalho, Ministério Público do Trabalho. Processo Judiciário do Trabalho e Disposições Finais $e$ Transitórias. 0 primeiro compreende normas sôbre o campo de aplicação da Consolidação e respectivas exclusões, a definição de empregador e empregado, a de serviço efetivo, as fontes do direito do trabalho, a prescrição e a afirmação dos princípios de salário igual para trabalho igual e de continuidade do contrato individual de trabalho. $O$ segundo título versa sôbre identificação profissional, duração do trabalho, salário mínimo, férias, higiene e segurança do trabalho. O terceiro trata das disposições especiais sôbre duração e condições de trabalho, nacionalização do trabaIho, proteção do trabalho da mulher e proteção do trabalho do menor. O quarto sôbre disposições gerais, relativas ao contrato individual de trabalho, remuneração, alteração, suspensão e interrupção, rescisão, aviso prévio, estabiliđade, fôrça maior e disposições especiais. O quinto versa sôbre instituição sindical, enquadramento sindical e impôsto sindical. O título sexto versa sôbre contrato coletivo de trabalho. O título sétimo sôbre fiscalização, autuação e imposição de multas, recursos, depósitos, inscrição e cobrança. O título oitavo sôbre introdução, Juntas de Conciliação e Julgamento, Juízes de Direito, Tribunais Regionais do Trabalho, Tribunal Superior do Trabalho, serviços auxiliares da Justiça do Trabalho, penalidades e disposiçoes gerais. $O$ título nono trata de disposições gerais, Procuradoria da Justiça do Trabalho e Procuradoria da Previdência Social. O título décimo versa sôbre disposições preliminares, processo em geral, dissídios individuais, dissídios coletivos, execução, recursos, aplicação das penalidades e disposições finais. $O$ título décimo primeiro trata das disposições finais e transitórias.

Numa apreciação geral da Consolidação das Leis do Trabalho é fácil apontar desde logo alguns defeitos, sem embargo do grande benefício que ela veio trazer ao ordenamento jurídico-social brasileiro, livrando-nos do mare magnum de leis em que nos submergimos. 
Assim é que, preliminarmente, pelo motivo apontado, a Consolidação não é apenas uma Consolidação, pois inovou no direito vigente. Assim, o decreto-lei n. 5.452, de 1. ${ }^{\circ}$ de maio de 1943, declara expressamente: "Fica aprovada a Consolidação das Leis do Trabalho... com as alterações por ela introduzidas na legislação vigente" A exposição de motivos do Sr. Ministro do Trabalho diz expressamente: "Não é a Consolidação exclusivamente, a reunião sistematizada de leis esparsas. Ponderou a comissão a definição dos rumos políticos traçados pela Constituição de 10 de novembro de 1937, a ela subordinando as leis consolidadas. Ainda em cumprimento aos preceitos constitucionais foram preenchidas algumas lacunas e excluídos dispositivos que com aquelas colidiam". E se refere ainda a que: "O regimen de férias foi estendido aos trabalhadores: rurais" E o mesmo diz a exposição de motivos da Comissão. Ademais disto, excluiu do campo de sua aplicação os empregados domésticos, estabeleceu a obrigatoriedade da carteira profissional, suprimiu a limitação das férias aos que apenas trabalhassem para um só empregador, renovou: inteiramente o capítulo "versando os fundamentos da proteção ao trabalho da mulher", fixou as responsabilidades do subempreiteiro perante os empregados, dando a êstes: direito de reclamar contra o empreiteiro, declarou as gorjetas incluídas no conceito de salário, criou o direito a uma indenização reduzida em certos casos assemelhados, à fôrça maior, conceituando a esta diversamente do disposto no Código Civil (art. 1.058, parágrafo único), aprimorou o contrôle da gestão financeira dos sindicatos, restabeleceu a competência da autoridade político-administrativa para extensão dos contratos coletivos de trabalho, deu às Juntas e Juizes de Direito competência não só para processarem, mas também para julgarem os inquéritos contra empregados garantidos com estabilidade, inovou em matéria processual do trabalho, introduziu o recurso extraordinário por violação expressa do Direito e criou o instituto do prejulgado, etc., etc.. Assim sendo, não se limitou a consolidar, fêz obra de codificação, isto é, aproveitou os elementos sadios: 
já existentes, substituiu ou suprimiu os que julgou imprestáveis e decadentes e preencheu lacunas. Logo, elaborou - embora incompleto - um código e não uma consulidação das leis do trabalho. Embora aprovemos essa atuação, não podemos deixar de perguntar: Por quê, então, dar-lhe um nome impróprio? Por outro lado, devido aos seus graves defeitos de sistemática não chega a ser um Códigoo.

O período atual de vigência da Consolidação das Leis do Trabalho, já nos permite aventar a oportunidade de: outras reformas não contempladas nas modificações que acabamos de passar em revista.

Assim é que, em primeiro lugar cumpre adaptar a Consolidação das Leis do Trabalho às novas diretrizes traçadas pela Constituição de 1946. Ademais disto, o progresso do Direito Social Brasileiro está a impor a sua codificação e é necessário dar à nossa legislação social orientação mais democrática, havendo, notadamente três problemas sôbre os quais se faz mister ponderar mais demoradamente: os da estabilidade, sindicalização e organização da Justiça do Trabalho. Iremos examinar sintèticamente tais questões.

Já criticamos a falta de método na ordenação do material legislativo consolidado na Consolidação das Leis do Trabalho. Os seus elaboradores até certo ponto se perderam em meio ao cipoal da legislação esparsa com que tiveram de defrontar-se ("quasi per medium profundum euntes. ") e daí talvez decorra essa carência de orientação segura nela verificada, conseqüência também do regimen de improvisação que tem caracterizado as nossas leis sociais.

Daí é fácil deduzir-se, máxime tendo-se em vista a importante repercussão das leis sociais na economia de um pals, quanto será benéfico um Código do Trabalho que viesse fixar, de maneira òbviamente não imutável, mas, pelo menos com uma certa e indispensável permanência, os princípios informadores de nossas leis trabalhistas, com maior amplitude que os poucos preceitos constantes da Consolidação, mas também com menos prolixidade que as nossas: 
por demais numerosas leis de proteção ao trabalho (Plurimae leges, pessima respublica). Ademais disto, um Código, de certo modo, imporia mais respeito aos próprios legisladores, amortecendo o afã reformador, que como vimos, nem por incidir quase sempre sôbre minúcias, deixa de perturbar menos os aplicadores das leis.

Esta legislação, entretanto, em muitos casos exagerou a intervenção estatal, dispondo sôbre assuntos que seria melhor deixar à livre estipulação das partes (no caso, os sindicatos), através dos contratos coletivos de trabalho. Outras medidas ainda, em lugar de ficarem sob a exclusiva e direta responsabilidade dos empregadores, melhormente seriam realizadas pelas instituições de previdência social.

5. Muito embora promulgada em data relativamente recente (1. ${ }^{\circ}$ de maio de 1943), a Consolidação das Leis do Trabalho, já passou por numerosas alterações. Depois do Decreto-lei n. 5.452, de 1-5-43, que aprovou a Consolidação das Leis do Trabalho, várias outras disposições legais foram aparecendo introduzindo modificações na legislação vigente, à medida em que tais modificações se iam patenteando necessárias. Entre 1-5-43 (data da promulgação da Consolidação das Leis do Trabalho), até 18-9-46 (data da publicação da atual Constituição Federal Brasileira), nada menos de 28 decretos-leis modificaram dispositivos da Consolidação, dos quais 21 ainda continuam em vigor e sete foram revogados. $\mathrm{E}$, posteriormente, foi promulgada a lei n. 605 , de 5-1-49, que veio estabelecer o descanso semanal remunerado. É verdade que não são modificações de importância, pois em sua quase totalidade versam sôbre questões de pormenor. Não sofreu, portanto, nenhuma reforma, pôsto que esta deveria ser orientada por um plano, o que não acontece em relação às modificações até agora havidas.

As alterações sofridas pela Consolidação das Leis do Trabalho podem agrupar-se em duas classes: a) as decor. rentes do estado de guerra que o Brasil atravessou de 1942 a 1945 e relativas a medidas tendentes a garantir a segu- 
rança nacional e a incentivar a produção e que, conseqüentemente, foram tôdas medidas de caráter transitório, cuja vigência cessou algum tempo depois do advento da paz; b) modificações de caráter permanente, votadas quase tồdas a facilitar a aplicação das normas a que se referiam, verdadeiras medidas de adaptação, portanto.

A nossa Carta Constitucional, no seu art. 157 contém vários dispositivos que alteram a legislação social vigente e dependem de regulamentação pela lei orảinária. Já acenamos a alguns dêles, estando mesmo um já regulamentado (o repouso remunerado, regulado pela lei n. 605, de 5-1-49), enquanto outros estão em estudos no Parlamento, tais como os referentes ao salário mínimo familiar, à participação dos empregados nos lucros das emprêsas e ao reconhecimento do direito de greve.

6. Em 1949, o Ministro do Trabalho, Professor HonóRIo Monteiro, nomeou duas Comissões para prepararem, uma, de que fazíamos parte, o anteprojeto de um Código do Trabalho e outra, para elaborar o anteprojeto do Código de Processo do Trabalho.

A Comissão do Código do Trabalho, depois de realizar várias reuniões, suspendeu os seus trabalhos, em abril de 1951, devido a mudanças no Govêrno Federal, inclusive na Pasta do Trabalho.

A Comissão do Código Processual do Trabalho conseguiu terminar o anteprojeto, apresentando-o ao Ministro do Trabalho, em 5 de maio de 1952. Declarou ela que procurou dar cabal auto-suficiência ao Código Processual do Trabalho, tornando o mais possível excepcional a remissão ao Código Processual Civil, embora aproveitando muitas normas dêste e mantendo quanto às provas o princípio inquisitivo, de acôrdo com o sistema constante da CLT ${ }^{4}$. O anteprojeto contém 307 artigos, classificados em seis livros:

4. Anteprojeto de Código Processual do Trabalho- Exposição de Motivos, in revista "Trabalho e Seguro Social", ns. 113 e 114, de 1952, pgs. 106 a 114. O texto do anteprojeto consta da mesma revista, ns. 119 e 120, de 1952, pgs. 236 a 257. 
I - Disposições Gerais; II - Do processo em geral; III Processo de competência originária dos tribunais; IV Dos recursos; V - Da Execução e VI - Disposições fỉnais e transitórias. Encaminhando-o ao Presidente da República, o Ministro da Justiça o condenou, acusando-o de ter aceito, sem maior crítica "o presente judiciarismo da Justiça do Trabalho", que considerava incompaüvel com a missão da Magistratura do Trabalho, concluindo que a Justiça do Trabalho carece de uma revisão quanto às suas finalidades e ao seu enquadramento, revisão esta que deverá ser feita ao elaborar-se o Código do Trabalho ${ }^{5}$, não sendo imprescindível o Código de Processo do Trabalho.

Pela Portaria n. 38, de 13 de abril de 1956, o Ministro do Trabalho nomeou nova Comissão para elaborar um anteprojeto de Código do Trabalho. E o Diretor da Divisão de Higiene e Segurança do Trabalho, do Ministério ảo Trabalho, pela Portaria n. 3, de 24 de janeiro de 1956, nomeou outra Comissão para elaborar o anteprojeto do Código de Segurança do Trabăho.

7. Posteriormente à vigência da CLT, foram apresentados ao Parlamento brasileiro dois projetos de Código do Trabalho; o do deputado José de Segadas Viana, antigo Ministro do Trabalho e o do deputado Carlos Lacerda, que passaremos a examinar sucintamente.

8. O projeto n. 606 , de 1950 , do deputado trabalhista Segadas Viana, instituiu o Código do Trabalho. Objetiva êle adaptar a legislação do trabalho vigente ̀̀ Constituição de 1946, aproveitando, para tanto, não sòmente as leis já promulgadas após ela, como também os projetos de lei sôbre participação direta dos empregados nos lucros das emprêsas (Projeto deputado Paulo Sarazate), os que regulam o direito de greve e o de organização sindical (com

5. Em tôrno do anteprojeto do Código Processual do Trabalho. Exposição do Ministro da Justiça contrária a aprovação dessa obra, in. Trabalho e Seguro Social", ns. 127-128, de 1953, pgs. 238 a 241. 
elementos inclusive o projeto do deputado JoÃo Mangabeira), incluindo dispositivos sôbre o salário mínimo familiar e sôbre empregados domésticos, corretores de publicidade, radialistas e motoristas profissionais.

Sua estrutura, salvo algumas alterações quánto à ordem de colocação de certos institutos, é fundamentalmente a mesma da CLT, sendo, portanto, em nossa opinião passível das mesmas críticas que aquela. Exclui os áispositivos referentes à organização da Justiça do Trabalho, por estar em curso a seu respeito um projeto de Lei Orgânicá e ao processo nos tribunais trabalhistas, que o Autor do projeto considera dever constar de lei especial.

Éste projeto pràticamente não teve andamento na Câmara dos Deputados, razão pela qual não nos estenderemos a seu respeito.

9. Em 1955, o deputado udenista (conservador) CarLos LACERDA, apresentou novo projeto, o de n. 429-1955, instituindo o Código do Trabalho. Além dos objetivos já visados pelo projeto anterior, pretende notadamente suprimir os dispositivos tipicamente regulamentares, incabíveis em lei, deixando em anexo ao Código a regulamentação especial das profissões. Inova principalmente estendendo a legislação do trabalho ao empregado rural, instituindo indenização de caráter creditório em caso de despedida injusta, aposentadoria ou morte do empregado, estendendo a garantia da estabilidade a todos os empregados e aumentando a indenização de antiguidade de certos empregados e tornando completamente livre a constituição e funcionamento das associações profissionais e dos sindicatos, abolindo o enquadramento sindical e o impôsto sindical, tornando obrigatório o regulamento interno em emprêsas com mais de 100 empregados, atribuindo à Justiça do Trabalho a extensão das convenções coletivas de trabalho. Exclui do Código a organização judiciária, o processo e o seguro social, que, na opinião do Autor do projeto, devem constar de leis ou códigos à parte. A orientação geral do 
projeto foi "conservar todos os direitos já existentes, aprimorar os incertos e criar novos". Adota confessadamente a tese estatutária ou institucional da "relação de emprêgo", denominação esta que substitui à de "contrato individual de trabalho", constante da cLT no Título IV.

Como o anterior, salvo as exclusões feitas, mantém pràticamente a mesma estrutura da cLT. Contém 412 artigos, enquanto o projeto Segadas Viana encerra 657 e a CLT 922 artigos. Deve-se isto às supressões feitas de dispositivos considerados regulamentares, notadamente muitos dos concernentes à higiene e segurança do trabalho.

É um trabalho notável que em sua publicação oficial ${ }^{6}$ coloca lado a lado os seus dispositivos e os da CLT, facilitando o seu confronto. Ao pé dos dispositivos, contendo inovações, há numerosas notas justificativas, com substanciosos fundamentos doutrinários. Entretanto, também êle não teve andamento parlamentar, sendo remetido em 1956 à Comissão de que nos ocuparemos no parágrafo seguinte.

10. Em 1955, foi criada no Congresso Brasileiro uma Comissão Mista de 9 senadores e 9 deputados para proceder à revisão da clt. Esta Comissão, instalada em 30 de abril de 1956, tem tido o seu mandato sucessivamente prorrogado. A ela foram incorporados, em 1957, como assessôres, três Procuradores do Ministério do Trabalho, Drs. Arínaldo Lopes Sussekind, Evaristo de Moraes Filho e Bríaido TiNoco. Elaboraram êles um esquema de projeto de Código do Trabalho, tendo em vista que a revisão da cLt e leis subseqüentes objetiva a elaboração daquêle projeto. Tomaram como diretrizes manter os princípios doutrinários da CLT, salvo em caso de incompatibilidade com a Constituição de 1946. Incluem no seu texto normas de Direito Individual do Trabalho, Direito Coletivo do Trabalho, Direito Administrativo do Trabalho e Direito Processual do Trabalho, deixando para leis especiaîs a Organização Ju-

6. Diário do Congresso Nacional, Capital Federal, Secção I, Suplemento ao n. 99, de 15-7-55. 
diciária do Trabalho e o Ministério Público do Trabalho e colocando como anexos ao Código as regulamentações profissionais especificas.

É a seguinte a estrutura proposta para o projeto do Código do 'I'rabalho: "Título I — Introdução; tí́rulo II Direito Individual do Trabalho, com os seguintes Capítulos: I - Da Relação de emprêgo, com as seguintes Secções: I - Do Contrato individual de trabalho; II - Da Remuneração; III - Da Alteração; IV - Da Suspensão e interrupção; V - Da Rescisão; VI - Do Aviso Prévio; VII — Da Estabilidade; VIII - Da Fôrça Maior; IX - Da Partıcipação nos lucros; II - Das Relações especiais de emprêgo, com as seguintes Secções: I - Do Contrato de prova; il - Do Contrato de aprendizagem; III - Do Trabalho em domicílio; Capítulo III - Do Regulamento de emprêsa; Capítulo IV - Da Tutela do trabalho, com as seguintes Seccões: I - Da Identificação Profissional; II - Da Jornada do Trabalho; III - Do Repouso semanal e em feriados; IV - Das Férias anuais; V - Do Salário Mínimo; VI - Da Higiene e Segurança do Trabalho; VII - Da Nacionalização do trabalho; VIII - Do Trabalho da mulher; IX - Do Trabalho do menor; $\mathrm{X}$ - Disposições finais (Referência aos Regulamentos especiais); rítulo III - Direito Coletivo do Trabalho, com o seguinte Capítulo: I Da Organização sindical, com as seguintes Secções: I - Dos direitos sindicais; II — Da associação profissional; III — Da instituição do sindicato; IV - Das associações sindicaîs de grau superior; V - Da administração e funcionamento; VI - Das eleições sindicais; VII — Da contribuição sindical; VIII - Disposições gerais; Capítulo II — Da Convenção Coletiva do Trabalho, com as seguintes Secções: I Disposições preliminares; II - Da Convenção de emprêsa; III - Da Convenção de categoria; Capítulo III — Dos Conflitos coletivos de trabalho, com as seguintes Secções: I - Dos dissídios coletivos; II - Da greve; III - Do "lock-out"; Título IV - Direito Administrativo de Trabalho, com o seguinte Capítulo: I — Da inspeção do trabalho, com as seguintes Secções: I — Da fiscalização; II — Das 
penalidades; III - Da autuação e aplicação de penalidades; IV - Dos recursos; V - Do depósito, inscrição e cobrança das multas; Título V - Direito Processual do Tra balho, com os seguintes Capítulos: I - Disposições Preliminares; II - Do processo em geral; III - Dos dissídios individuais; IV - Dos conflitos coletivos, com as seguintes Secções: I - Do processo de dissídio coletivo; II - Do processo de solução de greve e "lock-out"; V - Dos recursos; VI - Da Execução; VII - Penalidades; tírulo VI - Disposições finais e transitórias - Anexos: Regulamentações especiais".

Em 29 de março de 1958 os mesmos Assessôres fizeram entrega da Introdução ao Códīgo do Trabalho, que é a seguinte: “Art. $10^{\circ}$ - Êste Código estatui as normas que regulam as relações individuais e coletivas do trabalho. Art. $2 .^{\circ}$ - É livre o exercício de qualquer profissão, observadas as condições de capacidade que a lei estabelecer. Art. $3 .^{\circ}$ - Empregador é a pessoa natural ou jurídica que utiliza serviços de outrem em virtude de um contratō de trabalho. Parágrafo único - Sempre que uma ou mais emprêsas, tendo embora, cada uma delas, personalidade jurídica própria, estiverem sob a direção, contrôle ou administração de outra, constituindo grupo industrial, comercial ou de qualquer outra atividade econômica, serão, para os efeitos da relação de emprêgo, solidàriamente responsáveis à emprêsa principal e cada uma das subordinadas. - Art. $4 .^{\circ}$ - Empregado é a pessoa natural que presta serviços não eventuais a outrem, sob a sua subordinação jurídica e mediante salário. - Art. 5..$^{\circ}$ - Não haverá distínçōes relativas à espécie de emprêgo e à condição de trabalhador, nem entre o trabalho intelectual, técnico e manual, no que concerne a direitos, garantias e benefícios. - Art. $6^{\circ}{ }^{\circ}$ - Caracterizada a relação de emprêgo, não se distinguirá entre o trabalho realizado no estabelecimento do empregador e o executado em qualquer outro local, inclusive no domicílio do empregado. - Art. $7 .^{\circ}$ - A trabalho igual corresponderá salário igual, sem distinção de idade, sexo, nacionalidade ou estado civil. - Art. 8. ${ }^{\circ}$ - Considerar-se-á 
como de serviço efetivo, o período em que o empregado estiver à disposição do empregador, aguardando ou executando ordens, salvo disposição especial expressamente consignada. - Art. $9 .^{\circ}$ - Qualquer alteração na estrutura jurídica da emprêsa não afetará os direitos adquiridos por seus empregados. - Art. 10 - Serão nulos de pleno direito os atos praticados com objetivo de desvirtuar, impedir ou fraudar a aplicação dos preceitos contidos neste Código e nas demais leis de proteção ao trabalho. - Art. 11 - Na aplicação dêste Código atender-se-ão aos fins sociais a que êle se destina e às exigências do bem comum, de modo a que nenhum interêsse de classe ou particular prevaleça sôbre o interêsse público. - Art. 12 - Na falta de disposições normativas ou contratuais, as autoridades judiciárias e administrativas decidirão por eqüidade, por analogia, pelos usos e costumes e pelos princípios gerais do Direito, principalmente do Direito do Trabalho. Parágrafo único - O direito comum será fonte subsidiária do direito do trabalho, naquilo que não fôr incompativel com os princípios fundamentais dêste. - Art. 13 -- As leis de proteção ao trabalho terão efeito imediato e geral, aplicando-se aos contratos em curso, com as alterações que visem a beneficiar o trabalhador. - Art. 14 - Os preceitos constantes dêste Código, salvo quando expressamente determinado em contrário, não se aplicarão: a) aos empregados domésticos, assim considerados os que prestam serviços de finalidade não lucrativa para a pessoa do empregador ou de sua família, no âmbito de sua residência; $b$ ) aos funcionários públicos da União, dos Estados e dos Municípios, e aos respectivos extranumerários em serviço na própria repartição; c) aos servidores de autarquias paraestatais, desde que sujeitos a regimen próprio de proteção ao trabalho que lhes assegure situação análoga à dos funcionários públicos. Parágraîo único - Quando a União, ou autarquia por ela criada, adquirir emprêsas privadas, deverá no próprio ato aquisitivo ser fixado o regimen dos empregados da emprêsa adquicida. Em caso de omissão, continuarão as relações de emprêgo a ser regidas pelos preceitos dêste Código. - 
Art. 15 - Não havendo preceito especial em contrário, prescreverá em dois anos qualquer ação fundada em disposição dêste Código, contando-se o prazo da data em que puder ser ajuízada. $-\S 10^{\circ}-O$ prazo para ação contra alteração ilegítima das condições de trabalho começará a correr da data em que cessar a relação de emprêgo. — $₹ 2 .^{\circ}-$ Os prazos de decadência serão objeto de disposições especiais em cada caso. - Art. 16 - o regimen de seguro social e a organização judiciária do trabalho serão objetos $\mathrm{de}^{=\prime}$ leis especiais. - Art. 17 - As normas especiais do trabalho de determinadas profissões constituirão anexo dêste Código, tornando inaplicáveis as disposições gerais que regulem a matéria".

Em 3 de junho de 1958, o Relator Geral da referida Comissão, Deputado aARÃo Steinbruch renunciou ao seu. cargo e pediu a dissolução da mesma Comissão, afirmando que o Senado, a pretexto de sua existência, vem rejeitando sistemàticamente proposições oriundas da Câmara dos Deputados, modificadoras da CLT e alegando prejuízos para os trabalhadores, visto como um Código do Trabalho não poderia ser elaborado no fim de uma legislatura. Entretanto, esta solicitação não foi atendida, pois em 1959 a Comissão Mista de Revisão da CLT continuou funcionando.

A Federação das Indústrias do Estado de São Paulo, através da sua Assessoria Jurídica, de que fazemos parte, tem estudado atentamente os trabalhos daquela Comissão. Assim é que um dos Assessôres, o nosso eminente Colega, Dr. José de Anchieta Nogueira Júnior, em parecer ainda inédito, que gentilmente nos permitiu citar, se manifestou, com aprovação da Assessoria, no sentido de que, ao se elaborar o Código, é preciso atender a que os empregados também têm deveres, concomitantemente com os dos empregadores, e não sòmente direitos. Em seguida, analisou detidamente os dispositivos do Título introdutório do prójeto de Código do Trabalho, propondo vários aperfeiçoamentos aos seus dispositivos. Sobretudo estudou longamente e com profunda erudição, a definição de empregador, para condenar a definição do projeto, concluindo por ado- 
tar a seguinte: "Empregador é a pessoa natural ou juridica que, explorando a atividade de fins econômicos organizada em emprêsa, admite, assalaria e dirige a prestação pessoal de serviços" Esta definição foi aprovada pela Assessoria, contra o nosso voto, pois divergimos do ilustre Relator por considerarmos a emprêsa como pessoa jurídica ${ }^{7}$. Defende, com vigorosos argumentos, a subordinação jurídica do trabalhador como característica do empregado, conforme consta do projeto, substituindo a palavra "outrem", por "empregador"

Esta é, no momento, a situação do problema no Brasil.

11. A codificação das leis sociais tem sido tentada entre nós várias vêzes.

12. Assim é que, ainda durante a ditadura de Getúlro VARGas, tivemos o dl. n. 7.526, de 7 de maio de 1945 , que instituiu a Lei Orgânica dos Serviços Sociais do Brasil, o qual, na verdade, instituiu entre nós, um regimen à segurança social, unificando todos os órgãos de previdência social no Instituto dos Serviços Sociais do Brasil.

"Com o Decreto-lei n. 7.526, de 7 de maio de 1945, foi aprovada a nova Lei Orgânica dos Serviços Sociais do Brasil, na qual se previu a criação do Instituto de Serviços Sociais do Brasil (ISSB) - órgão que, todavia, não chegou a funcionar, porquanto o Govêrno empossado a 31 de janeiro de 1946 resolveu tornar sem aplicação o crédito aberto para sua instalação (Decreto-lei n. 9 481, de 18 de julho de 1946). Em conseqüência, a precitada Lei passou a ser àplicada apenas na parte que independia do funcionamento da nova autarquia. Esse Instituto absorveria tôdas as instituições de previdência social, realizando os seguros sociais de tôda a população que trabalha, bem como os serviços assistenciais configuradores do conceito da seguridade so-

7. Cf. nosso estudo Las personas en Derecho Social, no livro Estudios de Derecho del Trabajo en memoria de Alejandro M. Unsain", Buenos Aires, 1954, pgs. 33 a 38. 
cial. Com administração única e contrôle centralizado, teria o Instituto os órgãos que lhe permitiriam descentralizar a execução dos respectivos serviços. - Hoje, os planos atinentes à instalação dêsse instituto foram abandonados, eis que o Projeto da Lei Orgânica da Previdência Social, ora em curso na Câmara dos Deputados, apenas uniformiza a legislação respectiva, dando-lhe bases técnicas capazes de permitirem a execução dos seus fins, bem como a paulatina extensão do seguro social a tôda população que trah̆aha. Não se trata, todavia, de um plano completo de seguridade social, mas de um sistema de previdência social na sua moderna interpretação. O plano único de benefícios, ue custeio e de administração, no que tange aos Insitutos de Aposentadoria e Pensões, foi, porém, estabelecido pelo recente Regulamento Geral dêsses institutos, aprovado pelo Decreto n. 35.448, de $10^{\circ}$ de maio de 1954 , com base no que a respeito estatuíam o precitado Decreto-lei n. 7.526, de 1945 e outras leis pertinentes ao assunto.

Com o Decreto n. 36.132, de 3 de setembro de 1954, o Govêrno resultante da morte do Presidente GeTúlio Vargas resolveu revogar o Regulamento Geral dos Institutos de Aposentadoria e Pensões, que consagrara a desejada uniformização das normas de administração, de custeio e de benefícios concernentes aos referidos institutos. Com isto, foram restabelecidos os Regulamentos que vigoravam a $1 .^{\circ}$ de maio de 1954, motivo por que retornou a Previância Social Brasileira à diversidade de regimens, tão combatida por técnicos e leigos" 8 .

13. São de Sussexind estas informações: "Em 1947, o Deputado Aloisio Alves teve o mérito de apresentar ao Congresso Nacional um Projeto de Lei Orgânica da Previdência Social uniformizando diversas normas da administração e fixando o plano único dos benefícios. Posteriormente, o próprio autor reviu inúmeras disposições do Pro-

8. Arnaldo L. Sussakind, Previdência Social Brasileira, Rio, 1955, pgs. 68 e 69 . 
jeto e, finalmente, em 1952, participou das reuniões da Comissão Nacional do Ministério do Trabalho, durante as quais foi elaborado um novo texto, seguindo as linhas gerais do documento primitivo. Essa terceira redação, que constitui o projeto ora em discussão na Câmara dos Deputados, mereceu a aprovação do Presidente Getúlio Vargas, sendo de presumir que, com inevitáveis alterações, se transforme oportunamente em lei. — O Projeto da Lei Orgânica da Previdência Social, cujos objetivos teriam sido, em parte, atingidos com o revogado Regulamento dos Institutos de Aposentadoria e Pensões, representa, conseqüentemente, o documento configurador da tendência atual do nosso sistema previdenciário" 9 .

14. Rubens Maragliano, nosso Companheiro da Assessoria Jurídica da Federação das Indústrias do Estado de São Paulo e seu Vice-Presidente, realizou minuciosos estudos sôbre projeto de Lei Orgânica da Previdência Social, de que resultou magnífico livro ${ }^{10}$. Resume êle: "O projeto da Lei Orgânica da Previdência Social é um trabalho Iongo, distribuído em nove Títulos e abrangendo 215 artigos, pois que o substitutivo englobou, em um único plano, a proposição de autoria do deputado Aloisı Alves ( . $^{\circ}$ 996/ 47), com as modificações posteriormente introduzidas, e o projeto $n .^{0} 2.119 / 56$, de iniciativa do Poder Executivo, dispondo sôbre a estrutura administrativa da Previdência Social".

Este projeto consta de 205 artigos agrupados nos seguintes títulos e capítulos: Título: I - Introdução, com um único capítulo; título II - Dos Segurados, dos Dependentes e da Inscrição, com os seguintes capitulos: I - Dos Segurados; II - Dos Dependentes; III - Com 2 Secções: I Da Inscrição dos Segurados e Dependentes; II - Da Inscrição das Emprêsas; título III - Das Prestações, com os

9. Ob. cit., pg. 79.

10. A Previdência Social e sua Lei Orgânica, São Paulo, 1958, pg. 23. 
seguintes capitulos: I — Das Prestações em geral; II - Do auxílio-doença; III - Da Aposentadoria por invalidez; IV - Da Aposentadoria por velhice; V - Da Aposentadoria especial; VI - Da Aposentadoria por tempo de serviço; VII - Do auxílio-natalidade; VIII - Do pecúlio; IX - Da assistência financeira; X - Da pensão; XI - Do auxíiioreclusão; XII — Do auxílio-funeral; XIII — Da assistência médica; XIV - Da assistência alimentar; XV - Da assistência habitacional; XVI — Da assistência social; XVII Da assistência reeducativa e de readaptação profissional; XVIII — Disposições diversas; Título IV — Do custeio, com os seguintes capítulos: I - Das fontes de receita; II - Do salário de contribuição; III — Da arrecadação, do recolhimento de contribuições e das penalidades; Título $\mathrm{V}-D a$ Administração, com os seguintes capítulos: I - Da estrutura administrativa; II - Dos órgãos de orientação e contrôle, com as Secções: I - Do Departamento Nacional de Previdência Social; II - Do Conselho Superior de Recursos da Previdência Social; III - Do Serviço Atuarial; IV Disposições diversas; Título VI - Das Instituições de Previdência Social, com os seguintes capítulos: I - Dos Institutos de Aposentadoria e Pensões, com as Secções: I — Da Administração e seus fins II - Do Conselho Administrativo; III - Do Conselho Fiscal; IV - Da Junta de Julgamento e Revisão; V — Dos Recursos e das Revisões; II Do Serviço de Alimentação da Previdência Social; III — Do Instituto da Casa Popular; IV - Disposições comuns às instituições, com as Secções: I - Da Aplicação do Patrimônio; II - Das Comunidades de Serviço; III -- Disposições diversas; título VII - Da Dívida da União; título VIII — Disposições gerais e transitórias, com as Secções: I - Disposições gerais; II - Disposições transitórias.

Êste projeto oriundo da Câmara dos Deputados, onde tinha o n. 2.119, de 1956, recebeu no Senado Federal, o n. 10, de 1958. Foi aí longamente debatido, sendo afinal aprovado em abril de 1960, com cêrca de 70 emendas, de- 
vendo assim retornar à Câmara dos Deputados para apreciação das mesmas ${ }^{11}$.

E' óbvio que não nos cumpre examiná-lo aqui quanto ao seu mérito, pois apenas o encaramos dentro do objetivo desta tese: a codificação das leis sociais. Dêste ponto de vista, não há dúvida de que é aceitável, apresentando uma estrutura metódica e baseada nos modernos ensinamentos da segurança social.

15. O problema da codificação das leis sociais não é de todo pacífico, no Brasil, como se poderia pensar depois de se verificar a existência, entre nós, de tantas comissões e projetos tendentes à elaboração de Códigos do Trabalho, do Processo do Trabalho, de Segurança do Trabalho e da Lei Orgânica da Previdência Social.

No Parlamento brasileiro vozes se têm levantado contra ela, como a do deputado Antônio Horácio que, na sessão da Comissão de Legislação Social, da Câmara dos Deputados, de 26 de outubro de 1955, declarou que deveria ser rejeitada preliminarmente a idéia de um Código do Trabalho, que considera prematura. Para êle, a cLT já lhe parece um progresso suficiente, uma vez que a legislação trabalhista está nos seus primórdios, que os seus princípios não estão bem delineados, não estando ainda cristalizados, como prova a diversidade de projetos apresentados sôbre assuntos trabalhistas. Entende que um Código do Trabalho votado nessas circunstâncias estaria sujeito a mudanças contínuas, tumultuando ainda mais a matéria ${ }^{12}$. No mesmo sentido se havia manifestado u'a mesa redonda reunida em 1951, no Rio de Janeiro, pela Federação das Associações Comerciais do Brasil, considerando prematura a idéia de

11. O projeto em referência foi aprovado pela Câmara dos Deputados e sancionado pelo Presidente Juscelino Kubitschek de Oliveira com a lei n. 3.807, de 26 de agôsto de 1960, publicada no Díário Oficial $d a$ União, de 5 de setembro de 1960.

12. Cf. Diário do Congresso Nacional, Secção I, de 1-11-55, pg. 8.010. 
elaborar um Código do Trabalho è preconizando apenas a revisão da CLTT $^{13}$.

$\mathrm{Na}$ IV reunião Plenária da Indústria, realizada em Goiânia, em janeiro de 1960, sob os auspícios da Confederação Nacional da Indústria e da Federação das Indústrias do Estado de Goiás, Nerio Battendieri, sem tratar pròpriamente do problema da codificação, apresentou, entretanto, interessante sugestão no sentido de que é preciso diminuir a exagerada intervenção do Estado nas relações de trabalho, assegurando a CLT aos empregados um "tratamento máximo" e não o "tratamento mínimo" que lhe cumpria garantir, segundo a doutrina e impedindo, assim, o "desenvolvimento do espírito de autocomposição das classes", através das convenções coletivas de trabalho, regulação esta que lhe competia estimular e não tornar inútil, visto como a lei "nacional" não pode atender às imposições resultantes da conjuntura econômico-social de cada região ${ }^{14}$. Afirma, pois, que a revisão de nossa legislação do trabalho deve limitar-se a fixar apenas normas mínimas de proteção ao trabalhador, com a necessária flexibilidade para a sua devida adaptação às circunstâncias de tempo e de lugar.

Em nossa opinião, mesmo em se reconhecendo a existência de numerosos projetos de lei versando assunto de Direito Social ${ }^{15}$, nem porisso se deve condenar a idéia de uma codificação das nossas leis sociais. Todos os argumentos geralmente expendidos a favor da elaboração de um Código, a nosso ver, encontram inteira aplicação à realidade brasileira.

Apenas entendemos que devem ser elaborados três Códigos e não apenas um: o Código do Trabalho, contendo tôda a matéria relativa ao contrato individual de trabalho

13. Cf. Folha da Manhã, de São Paulo, de 21-7-55, pg. 1, do 2:० caderno.

14. Reformulação da Legislação do Trabalho, Rio, 1960, pgs. 13, 19 e 20 .

15. Existem atualmente (abril de 1960) em andamento na Ĉेmara dos Deputados, 166 projetos sôbre matéria trabalhista e no Senado Federal uma dezena dêles. 
(ou à relação de emprêgo, se assim se preferir) e no díreito coletivo do trabalho (direito sindical, convenção coletiva de trabalho, conflitos do trabalho); outro, o Código de Segurança Social, contendo a matéria do atual projeto de Lei Orgânica da Previdência Social e um terceiro, o Código Judiciário e Processual do Trabalho, contendo a lei orgânica da Justiça do Trabalho e as normas especificamente relativas ao seu funcionamento para a solução dos conflitos individuais e coletivos do trabalho.

A nosso vêr, não se justifica a existência nem de um Código de Segurança do Trabalho, assunto que deve caber ao Código do Trabalho, nem de um Código Profissional. contendo as regulamentações profissionais (de profissões liberais e outras) e as regulamentações especiais (trabalho de mulheres e de menores, etc.), matérias sem dúvida alguma pertinentes ao Código do Trabalho.

Em todos êles, porém, estamos de acôrdo em que a matéria deve ser tratada na sua forma mais geral possível, deixando-se as minúcias para serem reguladas pelas convenções coletivas de trabalho e quando isso não fôr de todo possível, pelos regulamentos baixados pelo Poder Executivo. 